\title{
Competition in the World Market, Diversity versus Market Protection
}

\author{
Caspar von der Crone \\ Graduate Engineer Agrarian Sciences \\ PhD-Student, University of Sopron \\ Faculty of Economics \\ Hungary
}

\begin{abstract}
The imposition of punitive duties on imports by the US Government is not new. Such measures have traditionally been a strategic trade policy instrument to protect domestic market participants. Another reason, however, is the different competitive conditions vis-à-vis third-country suppliers. The example of the poultry industry will be used to illustrate the obstacles and perspectives. In many countries, especially in South America and Thailand, production conditions are much more favorable than in most countries of the European Union due to the resources available.

In the past, the EU Commission has introduced customs duties on imports from third countries to protect agriculture. In the major exporting countries, Brazil, Thailand and the USA, import tariffs for market access were systematically adjusted. In fact, the production costs for poultry meat in these countries are significantly lower as no raw material components for animal processing, such as cereals or protein carriers, have to be imported. In addition, there are significantly lower labor costs, simplified requirements for working conditions and lower environmental and animal welfare requirements, as well as less stringent requirements for facilities and stables.
\end{abstract}

All these aspects lead to production costs up to one third below the EU average. In addition, the competitive advantage includes product specifications that correspond to those of the EU and compliance with global standards such as IFS (International Featured Standard) or BRC (British Retail Consortium).

Diversity aspects and trade effects on the world market are examined using Brazil as an example. Brazil is one of the largest poultry meat producers and the world's largest exporter of poultry meat. Over time, the EU Commission has installed several levers to control imports from Brazil, but also from other countries.

For this reason, threshold prices, customs duties and safeguard clauses have been set to protect EU producers. These are at odds with the GATT and WTO agreements and the objectives of the free trade agreements. The EU Commission continues to adhere to this. However, there are quotas at reduced or even suspended duties. The use is however bound to regulations. The elaboration is intended to present the effects of impairments and imbalances on world trade.

Keywords: diversity of production, production costs, market protection, global trade, standards

\section{The Situation}

Trade in poultry meat plays a special role within the European Union. At the beginning of the 1960s, the production of poultry meat in today's EU countries was still insignificant. The European Community was founded in 1967. At that time, poultry meat was imported from neighboring countries, but also from the USA. In the meantime, however, the situation has changed. The European Union is today one of the world's largest producers of poultry meat. Consumption is growing steadily, and the level of self-sufficiency is well above $100 \%$. While many years ago it was still necessary to meet the growing demand with imports, today poultry meat is exported to keep the market in balance. Despite increasing consumption, there is overproduction and production is continuously increasing. World trade in poultry meat and products is therefore very important and new markets are being developed.

Imports of poultry meat remained largely constant at just under one million tons. Imports are concentrated on high-quality boneless chicken meat, as it makes little sense to transport whole animals due to transport costs. The main export countries are Brazil and Thailand. But there is also trade in poultry meat within the EU, in particular turkeys, ducks and geese. The most important suppliers are France, Hungary and Poland. 
The European Union has created a large number of regulations and standards for regulation. These range from production requirements within the framework of marketing standards, hygiene standards, residue requirements, animal health regulations to traceability and traceability along the entire process chain.

This complicates trade relations with many countries. Many do not have access to the EU because the requirements cannot be met or implemented. Nevertheless, trade in poultry meat and other products remains of great interest. WTO agreements or free trade agreements with third countries should facilitate access to the EU. This results in a large number of agreements and quotas. The aim of these regulations is to harmonize access to the European Community, but also to control it. This is achieved through lower tariffs up to zero duty (e.g. the socalled oilseed panel for boneless poultry meat from Brazil and Thailand and other third countries).

The following contribution is intended to provide essential information on the trade mechanisms for trade in poultry meat from third countries.

\section{Hypotheses}

H1: EU rules affect market conditions to the detriment of domestic production.

$\mathrm{H} 2$ : Customs duties and regulatory restrictions determine the market and influence development within the EU and prevent the intra-Community development process.

H3: Quotas and quotas offer third countries (countries outside the EU) perspectives and investment opportunities to increase production and open up new markets. Who has the economic benefit?

H4: EU mechanisms have functionality

\section{Methodology}

The procedure initially includes an overview of the current regulations within the EU and the GATT and WTO agreements on international trade and competition. To this end, the existing quota systems, safeguard clause systems, customs duties and additional levies will be presented and assessed. In addition, a global market overview and foreign trade are essential to present the specifications. The topic is very complex and can therefore hardly be presented and interpreted in such a short overview. Nevertheless, an attempt is made to give an insight into EU legislation and its systematics.

\section{Global agreements}

WTO - World Trade Organization, Geneva

Objective: to reduce customs duties and quantitative restrictions on imports and exports. It was founded on 15 April 1994 under the GATT - General Agreement on Tariffs and Trade in the so-called Uruguay Round. Besides the IFW - International Monetary Fund, Washington and the World Bank (World Bank, Washington), the WTO is one of the most important international organizations negotiating global trade and economic policies.

TIPP - Transatlantic Trade and Investment Partnership (EU-US)

The aim of the negotiating third countries is to remove tariff and non-tariff barriers to trade between the USA and the EU.

Unfortunately, negotiations are stagnating, and the recent discussions and announcements of tariffs stand in the way of an agreement. oilseed panel The Common Market Organization (CMO) for oilseeds was reformed in 1991. Production aid was replaced by direct payments to farmers. The amount of the payments is based on the area used for oilseed production and the historical average yield of the region concerned. This results in the dutyfree quota for boneless poultry meat, in particular from Brazil and Thailand. threshold prices Market prices at which agricultural products may be imported into the European Union. The prices of agricultural products below the threshold prices are so much higher that they reach the threshold price due to taxes and duties, a very theoretical approach, but efficient. US punitive tariffs

US President Trump is serious about punitive tariffs and import restrictions. This is nothing new and quite common practice. In 2002, George W. Bush had the same idea. In order to protect the weakened steel sector of the generally weakening US industry, he imposed surcharges of 8 to 30 percent on imports. The EU and other countries immediately lodged a complaint with the World Trade Organization (WTO) and threatened to sanction US products as well. Thereafter, the US lifted the trade restrictions. 
As early as 1965, President Lyndon B. Johnson introduced the Chicken Tax as a punishment for European trade barriers to frozen chicken meat from the United States. It was an import duty of $25 \%$ on pick-up trucks as a countermeasure to the additional duties imposed by European countries on imports of American chickens. This duty still applies to pick-ups.

\section{Facts and figures}

Within the EU, Poland, Great Britain, France, Spain, Italy and Germany are the largest suppliers of poultry meat. In total, they account for $71 \%$ of total EU production. A total volume of just under 14.5 million tons has recently been achieved. This means that the demand is now clearly exceeded. The degree of self-sufficiency has been above $100 \%$ for years. Exports are therefore necessary to stabilize the market. The deliveries go to China, but also to Russia and the countries of the Middle East. Poultry meat is also delivered to Africa, especially to slaughter hens. Many years ago, there were export refunds for certain products. The aim was to facilitate access to thirdcountry markets, i.e. to compensate for higher production costs and thus the lack of competitiveness vis-à-vis other countries. However, this was contrary to WTO principles and export refunds no longer exist.

Figure 1: Poultry production and trade

Poultry Production and Trade

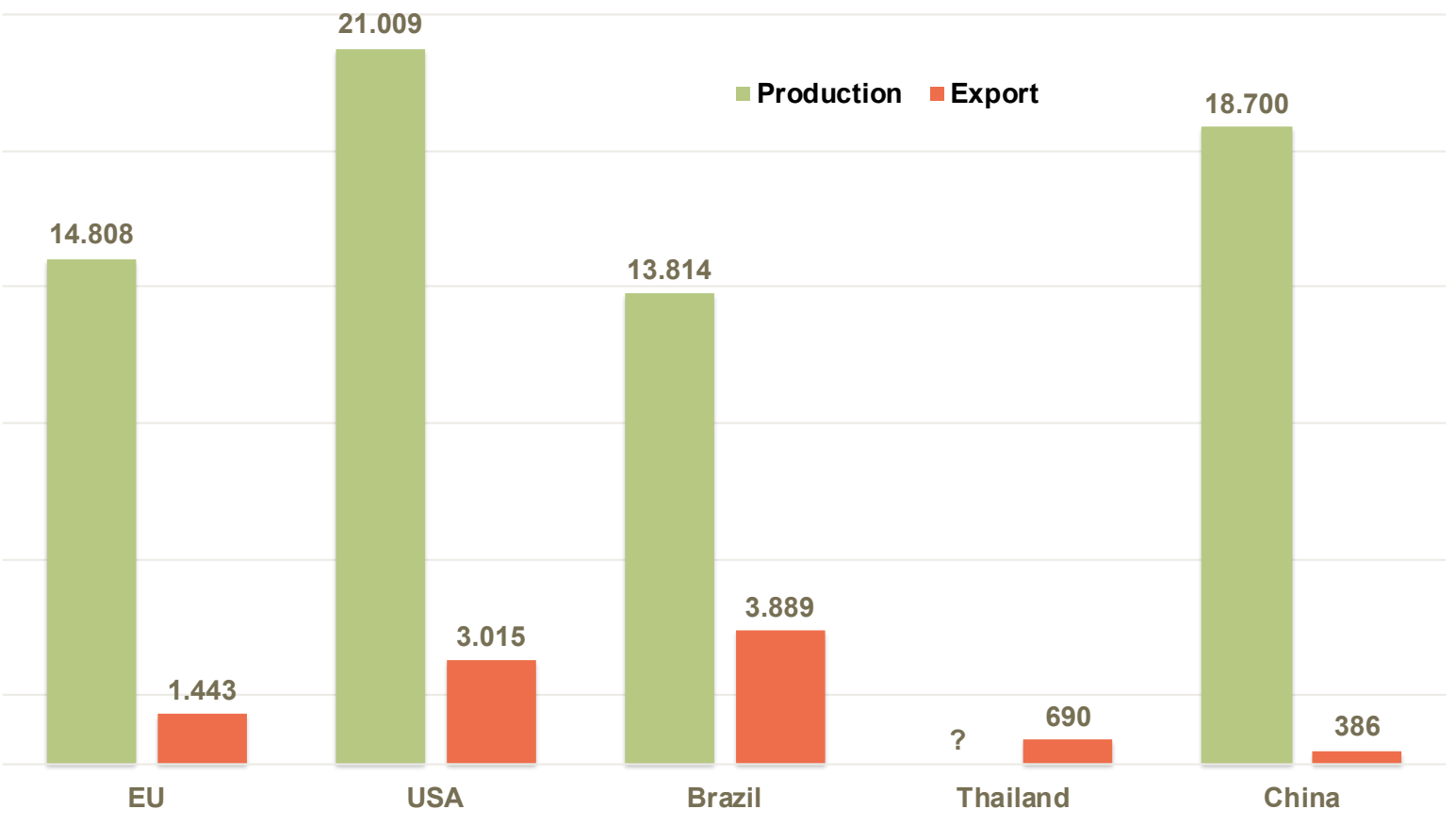

Source: Compiled by Caspar von der Crone, MEG balance eggs and poultry

The figure gives an overview of the world market for production and trade. The USA is the world's largest producer of poultry meat. China ranks second, followed by the EU countries and Brazil. Unfortunately, no concrete data are available for Thailand.

Brazil is the world's No. 1 exporter of poultry meat and exports almost 4 million tons of poultry meat. Important customer countries are the Middle East, but also countries of the European Community, especially Germany.

Currency parities play an important role in wholesale and foreign trade. In the past, therefore, there were currency compensation amounts to compensate for exchange rate differences within the countries of the then EU. With the introduction of the ECU and later the euro, this became obsolete. However, it may still be important for countries outside the euro zone.

Today, most foreign trade is conducted in US dollars. Therefore, a low or high dollar exchange rate still has an impact on the economic perspective.

The ups and downs of the US dollar against the euro in recent years has therefore played an extremely important role in trade. Example: The contract is concluded at a low dollar exchange rate; during processing, transport etc. 240 
the dollar exchange rate changes and has reached a higher level. This inevitably has an impact on sales and costing. Importers are achieving a significantly lower price on the market than previously expected. On the other hand, it can go just as well in the other direction. Between conclusion of the contract and delivery, marketing, dispatch and transport, etc., many weeks or months usually pass.

Figure 2: Broiler prices in EU, US and Brazil

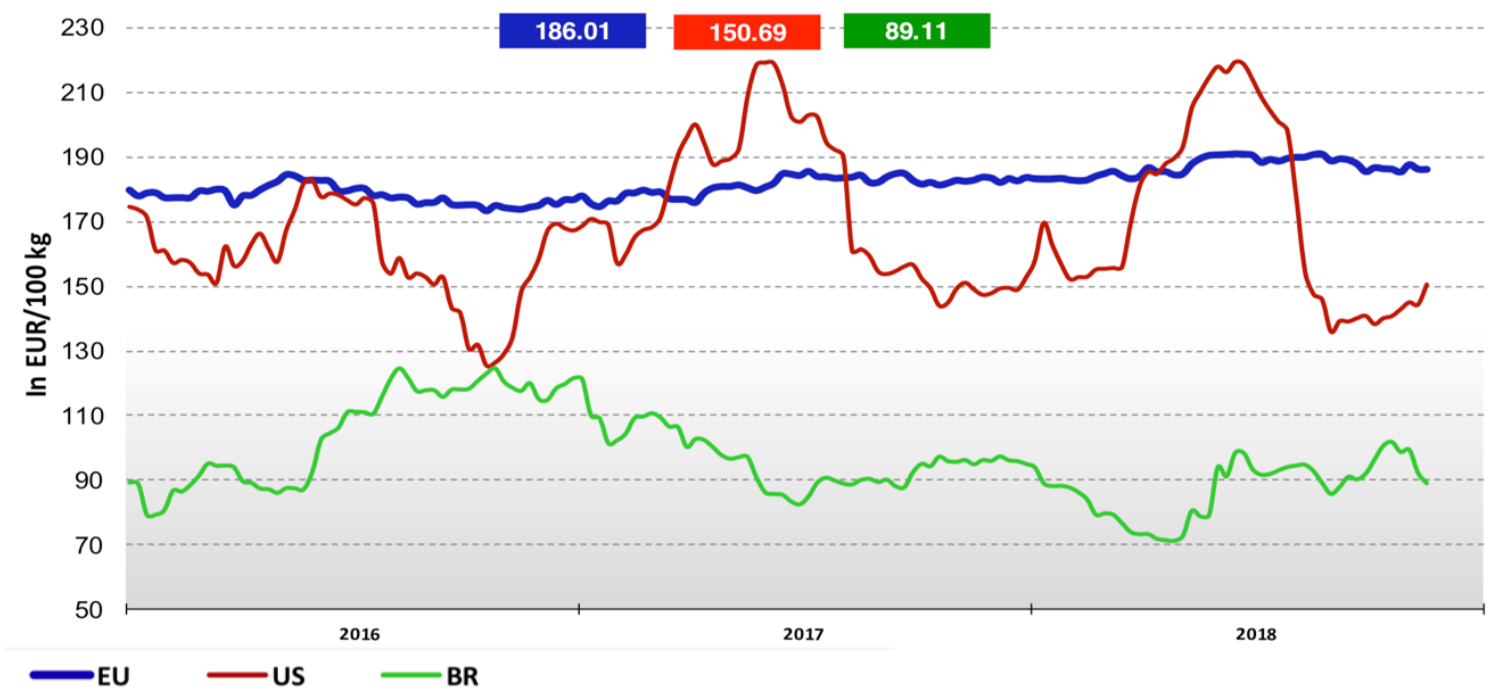

Source: EU Commission

The development of producer prices for broilers is characterized by a constant ups and downs. They clearly show the different production costs of poultry meat in Brazil, the USA and the EU. This results in competitive advantages. Brazil, in particular, is benefiting above all from the favorable framework conditions and thus significantly lower production costs. The reasons for this have already been explained. Production costs are also lower in the USA than in EU countries. In addition to ascending and descending exchange rates, feed prices play a decisive role. Crop failures and lower yields due to the drought in 2018 lead to higher costs, which have a direct impact on production costs, as feed is the main cost factor in animal refinement.

(a total of 871,547 tons in 2018)

Table 1: EU import quotas

\begin{tabular}{|c|c|c|c|}
\hline \multicolumn{2}{|c|}{ First come first serve, zero duty } & \multicolumn{2}{|c|}{ Minimum market access, red. rate of duty } \\
\hline Chile & 18.125 & USA & 21.345 \\
\hline Israel & 7.000 & third countries & 19.305 \\
\hline \multirow[t]{2}{*}{ Turkey } & 1.000 & & \\
\hline & & \multicolumn{2}{|c|}{ salted poultry meat, ad valorem duty } \\
\hline \multicolumn{4}{|c|}{ Licence quotas, zero duty rate } \\
\hline & & Brazil & 170.807 \\
\hline Israel & 4.560 & Thailand & 92.610 \\
\hline Brazil & 21.608 & & \\
\hline Thailand & 5.100 & \multicolumn{2}{|c|}{ Preparations, ad valorem duty } \\
\hline Ukraine & 37.600 & & \\
\hline \multirow[t]{2}{*}{ other } & 6.485 & Brazil & 250.482 \\
\hline & & Thailand & 189.633 \\
\hline Total & 871.547 & other & 25.877 \\
\hline
\end{tabular}

Source: EU Commission - EU market situation for poultry meat and eggs

The import quotas of the European Union are currently just under 0.9 million tons. There are various quota regimes ranging from zero to reduced duties. Of particular interest are imports of salted poultry meat and preparations (seasoned, cooked). The volume is now 0.7 million tons. 
The meat is not suitable for direct consumption, but only for further processing. These origins are subject to a fixed duty, so there are no risks from threshold prices or additional charges. In the case of salted poultry meat, the Commission has taken many steps in Brussels to reduce imports, and a quota has finally been created. With the customs tariff for salt meat, importers have found a gap in the customs tariff in order to handle import transactions at more favorable conditions.

\section{Standards and requirements}

In all areas of animal refinement there are standards for production and marketing. These can also restrict the import business. At the beginning of the 1960s there was neither the EU (the European Community - EC was founded in 1967) nor any significant production of poultry meat. At that time, Germany imported broiler chickens mainly from the USA. However, this trade has come to a standstill. The reason: Different hygiene requirements. The US poultry industry uses chlorine to reduce micro-organisms, which is not allowed under EU legislation. But also, the posture requirements have a big influence. For example, eggs from third countries which do not comply with EU requirements must be declared "not EU compliant". Products offered in this way can be marketed, but the labelling is tantamount to a marketing ban in food retailing.

Although the USA has for many years had continents with reduced tariffs for the supply of poultry and eggs to the EU, the export is difficult due to different hygiene requirements and marketing standards, keyword chickens. From a hygienic point of view this is completely unfounded, but rather an emotional aspect which has long been a point of discussion between the EU and the USA.

But that's only part of the story: Overall, the improved location conditions lead to production costs that are up to one third below the EU average, as the example of Brazil shows. Over the years, the EU Commission has therefore issued a large number of regulations in order to balance the competitive advantages over EU farmers.

The basic principle is based on threshold prices (theoretical production costs based on surveys carried out in the late 1980s) and additional duties, also known as punitive duties, on imports from third countries. The basis for this is no longer up to date due to the changed framework conditions. Productivity has improved significantly as a result of successful breeding. The animals reach an earlier slaughter age or carcass weight and have a better feed conversion. New standards in the field of equipment and slaughtering technology lead to a further increase in efficiency. Nevertheless, the EU Commission is sticking to outdated threshold prices, ultimately to protect poultry producers in the EU.

However, this procedure is contrary to the GATT (General Agreement on Tariffs and Trade) / WTO Agreement and the objectives of the free trade agreements with the Mercosur countries. Nevertheless, the EU maintains its approach. However, export refunds for deliveries to third countries were abolished.

\section{Supply Chain}

Figure 3: Example Supply Chain

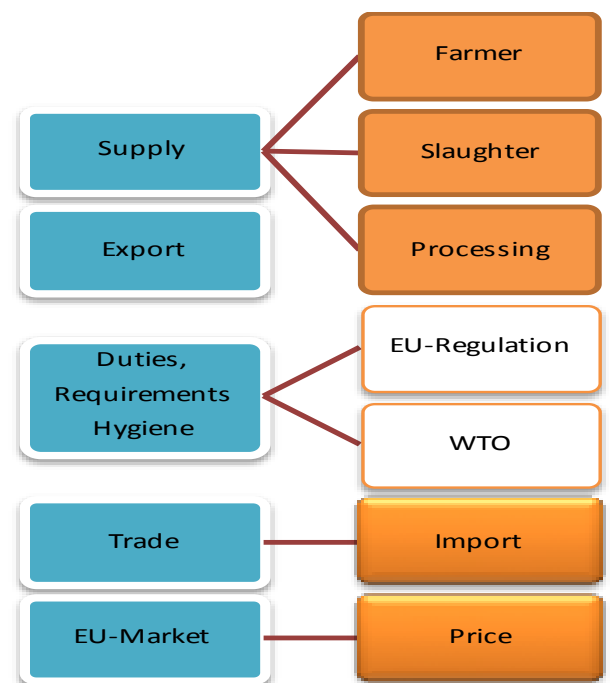

Source: CD Consulting gUG, Caspar von der Crone 
The overview is an example of the value chain in the poultry sector. But it also applies to other products and represents the process from production to marketing. In between, there are many rules before delivery and marketing takes place in the EU.

However, traceability and traceability of origin play a very important role. The EU Regulation 178/2002, which contains requirements for the origin of products, applies to foodstuffs placed on the market in Germany. This has led to an extensive discussion. In principle, regulation is to be welcomed, but it is not sufficient to cover the entire process chain. In the meantime, there are more and more approaches for further measures, for example Blockchain. Batch-oriented traceability offers traceability, especially when recalls have to be initiated due to residues. In addition to traceability, other aspects have also gained in importance. These include sustainability, fair prices and above all animal welfare.

In addition to market-relevant requirements, there are other criteria: These may be animal health requirements (avian influenza, ASF and other animal diseases) or residues which are subject to specific limits within the EU. In the past, there have been problems with antibiotic residues whose use is banned and where proof is provided, imports are refused. This also applies to salmonella and other prohibited substances, e.g. nitrofurans or dioxins. Prior to customs clearance, the containers are randomly inspected. If residues are found, importation shall be prohibited. The respective importer is not only responsible for the residue checks, but also for the risk of total loss during the disposal of the delivery.

\section{Customs duties, safeguard clause}

The most important requirements are listed below:

- threshold prices

- Duties, additional duties

- Safeguard clause systems

- oilseed panel

- WTO / GATT regulations

- Minimum market access (Minimum Access)

- TIP

- free trade agreements

- Common Agricultural Policy (CAP)

The EU Commission has created a complicated set of rules to protect agriculture. Duties on imports from third countries lead to market restrictions but are actually intended to compensate for the often significantly lower production costs compared to the EU.

Threshold prices have been in force since 1.7.1995 and have not been adjusted since then. Customs duties have remained unchanged since 2000. Representative prices are charged. On this basis, additional duties are calculated. This is intended to take account of the different framework conditions on the world markets. They are intended to compensate for lower production costs outside the EU.

An additional duty shall be levied if:

Import price $<10 \%$ below the threshold price $0 \%$.

Import price $>10 \%$ to $<40 \%$ below the threshold price of $30 \%$.

Import price $>40 \%$ to $<60 \%$ below threshold price $50 \%$.

Import price $>60 \%$ to $<75 \%$ below threshold price $70 \%$.

Import price $>75 \%$ below the threshold price of $90 \%$. 
Example: how it works:

Table 2: Example of calculation

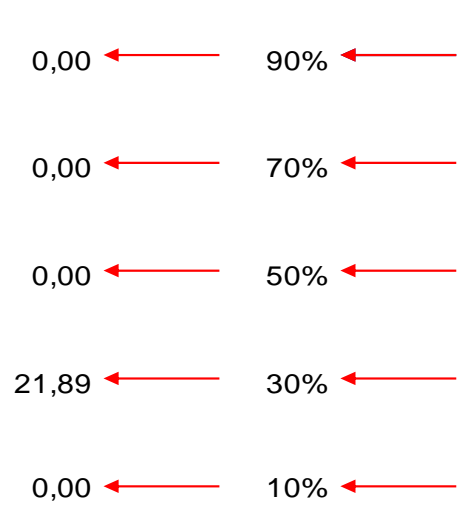

threshold price

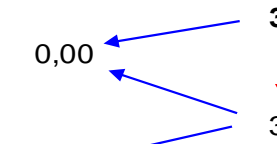

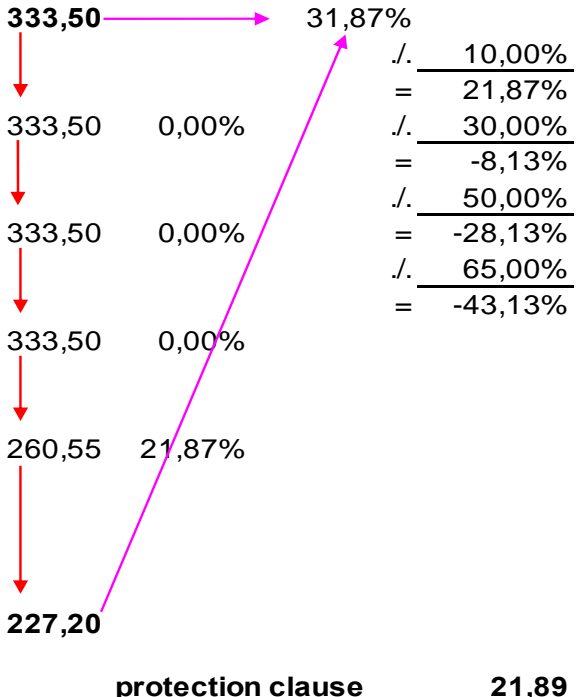

\begin{tabular}{lr} 
& EUR \\
\hline custums tarriffs & 102,40 \\
protection clause & $\mathbf{2 2 , 0 0}$ \\
\hline costs of carrige etc. & 0,20 \\
repäsenative Price & 227,20 \\
\hline offer price & $\mathbf{3 5 1 , 8 0}$
\end{tabular}

Compiled by EPEGA, Caspar von der Crone

It is a very complicated procedure. In the above example, the representative price or CIF import price was used. This results in an additional duty of $21.89 €$, rounded $22.00 €$. Zoo, additional duty, import price and transport etc. result in a theoretical offer price of $351,80 €$.

Figure 4: Theoretical price calculation for imports

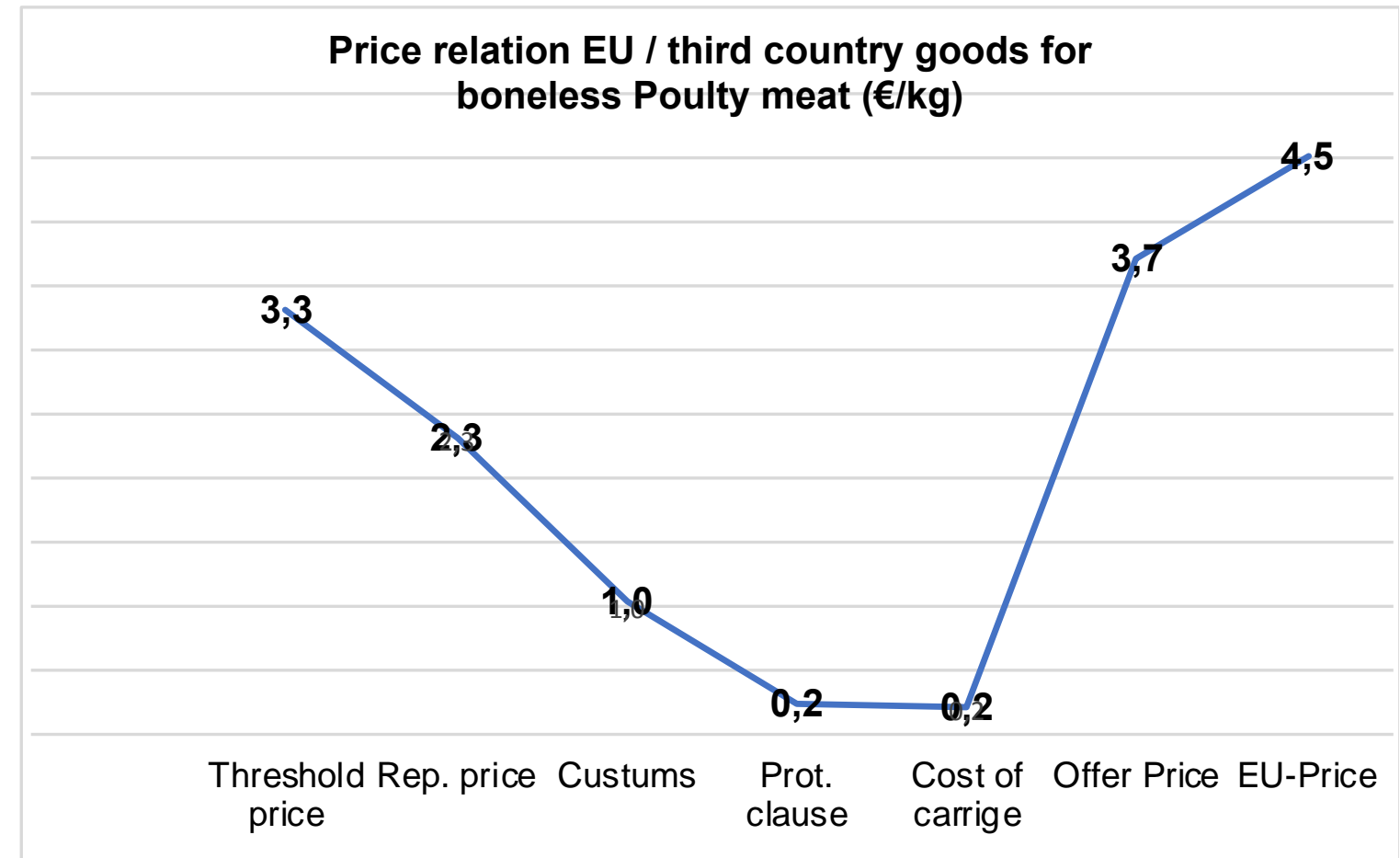

Compiled by CD Consulting, Caspar von der Crone 
The overview shall serve as a basis for calculating trade in poultry meat. The data are based on real values. Threshold prices and additional charges are fixed. Additional obligations, which vary according to the market situation, are regarded as factors of uncertainty. The transport and logistics costs are also calculable, but not the additional fees that arise from inspections and investigations in the ports. This results in a theoretical offer price for goods from third countries, in this case $€ 3.7$, which must not be lower than the EU market price.

\section{Evaluation of the hypotheses}

H1: EU rules affect market conditions to the detriment of domestic production

Quotas and association agreements open up prospects for countries outside the EU. However, the aim is to achieve production targets and adapt to market conditions. There is no discrimination against domestic production. Competition under the same conditions always makes sense and helps to distinguish oneself on the market. This also applies to countries outside the EU which are confronted with future requirements. This serves on the one hand to facilitate access to the EU market, but on the other hand also to implement experience with standards in the future production process. The presentations of the magnitudes of the quotas and the demand for imported goods clearly demonstrate this.

H2: Tariffs and regulatory restrictions determine the market and influence development within the EU and prevent the intra-Community development process.

No, the tariffs are intended to compensate for competitive advantages. In many countries there are better framework conditions than in the EU, e.g. low feed prices, climate, service, working conditions, lower wages and social aspects.

Evidence: The safeguard clause system and its impact on the price structure.

H3: Quotas and quotas offer third country suppliers perspectives and investment opportunities to increase production and open up new markets. Who has the economic benefit?

Both third countries and EU Member States. On the production side, it is considered that this distorts competition as there are production cost advantages for third parties, in particular Brazil and Thailand. On the other hand, the market and consumers benefit from favorable prices. Competition always serves change and cost-oriented management. Ultimately, however, the framework conditions and sales conditions, quality and food safety are decisive. In the past there have been problems with arrears and lack of controls. However, this has also led to changes in production and control procedures.

H4: EU mechanisms have functionality

Yes, the requirements are very efficient, even if they are complicated in application and implementation and not easy to understand. Proof of this is the safeguard clause system with the calculation of additional levies when goods are dumped on the EU market. The system is very efficient and comprehensively protects EU producers.

This applies to EU legislation, in particular marketing standards, but also to the general level of hygiene.

\section{Conclusions}

An additional duty shall be levied on the basis of representative prices collected by the EU in the exporting countries if these are below the threshold price. In addition, there are freight costs, handling costs in the ports, transport to the destination, handling and, if necessary, hygiene and residue checks.

But the economy finds other solutions: One example is the import of salted poultry meat, which does not fall under the threshold prices but only under the ad valorem duties. Import volumes have increased significantly and the EU has created a quota to regulate the volume of supplies from Brazil and Thailand. This shall also apply to cooked and prepared poultry meat.

The so-called oilseed panel stands for duty-free imports, especially from Brazil and Thailand. It comprises 27,000 tons, which theoretically leads to a profit of over 27 million euros. There is therefore a complicated procedure for restricting applications for authorizations. Many companies have founded up to 100 more companies to benefit from these quotas. For this reason, some of the allocation ratios are below $0.5 \%$.

But trading also entails risks. Deposits, royalties and, where applicable, advance payments forfeited if the allocated quantity is not accepted within a normally short period of time. 
The EU has developed a sophisticated system to protect agricultural production. In the meantime, export refunds (to offset competitiveness, in particular vis-à-vis other third countries) have been usefully abolished under the WTO agreements. Nevertheless, customs duties and, above all, additional duties hinder import trade. This was illustrated by the example of poultry meat.

Trade restrictions also result from production standards, legal requirements, the hygiene package, food law requirements, animal health and animal welfare. Suppliers must be approved by the EU and meet $100 \%$ of the requirements of the regulations.

\section{References}

\section{EPEGA}

https://epega.org, Association Circular 2002 of the European Association of Game and Poultry Wholesale and Foreign Trade e.V. (EPG), Publisher and Managing Director Caspar von der Crone, Archive of the Association, Konrad-Zuse-Platz 5, Bonn, Germany

\section{EUROSTAT}

https://ec.europa.eu/info/departments/eurostat-european-statistics_de

EU-Commission - EU marketsituationforPoultrymeatand Eggs

https://ec.europa.eu/agriculture/sites/agriculture/files/poultry/presentations/market-situation_en_2.pdf

EUR-Lex (Acces to European Union law)

http://eur-lex.europa.eu/homepage.html

GATT General Agreement on Tariffs and Trade (GATT), https://www.bmz.de/de/themen/welthandel/welthandelssystem/gatt/index.html

Minimum Access (determinatetCustums tariff), GATT

https://eur-lex.europa.eu/legal-content/DE/ALL/?uri=CELEX\%3A32007R0533

Oilseed Panel (Customs tariff Zero)

https://eur-lex.europa.eu/legal-content/DE/ALL/?uri=CELEX\%3A32007R1385

Tariff quotas for poultry meat originating in Brazil, Thailand and other third countries

https://eur-lex.europa.eu/legal-content/DE/ALL/?uri=CELEX\%3A32007R0616

Uruguay-Round

https://www.wto.org/english/thewto_e/whatis_e/tif_e/fact5_e.htm

WTO World Trade Organisation

https://www.wto.org/english/thewto_e/thewto_e.htm 